\title{
PHYSICAL IMPROVEMENT AND BIOLOGICAL MATURITY OF YOUNG ATHLETES (11-12 YEARS) WITH SYSTEMATIC TRAINING
}

Konstantinos E. Tilkeridis ${ }^{1 *}$, Evaggelos F. Theodorou ${ }^{1}$, Jannis V. Papathanasiou ${ }^{2}$, Pelagia A. Chloropoulou ${ }^{1}$, Grigorios A. Trypsianis ${ }^{1}$, Savvas P. Tokmakidis ${ }^{3}$, Konstantinos I. Kazakos ${ }^{3}$

${ }^{1}$ Department of Orthopaedics and Traumatology, Democritus University of Thrace, Greece, ${ }^{2}$ Department of Kinesitherapy, Faculty of Public Health, University of Sofia, Bulgaria, ${ }^{3}$ Physical Education and Sport Sciences, Democritus University of Thrace, Greece

\section{УЛУЧШЕНИЕ ФИЗИЧЕСКОГО РАЗВИТИЯ И БИОЛОГИЧЕКАЯ ЗРЕЛОСТЬ ПРИ СИСТЕМНЫХ ЗАНЯТИЯХ СПОРТОМ МОЛОДЫХ СПОРТСМЕНОВ (11-12 ЛЕТ)}

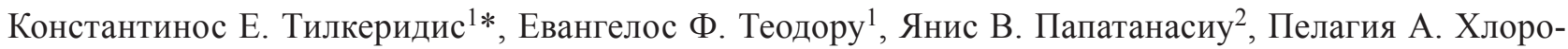
пулу ${ }^{1}$, Григориос А. Трипсианис ${ }^{1}$, Савас П. Токмакидис ${ }^{3}$, Константинос И. Казакос ${ }^{3}$

${ }^{1}$ Кафедра ортопедии и травматологии, Демокритский университет, Греция, ${ }^{2}$ Кафедра кинезитерапии, Факультет общественного здравоохранения, Медицинский университет,

София, Болгария, ${ }^{3}$ Факультет физического воспитания и спортивных дисииплин, Демокритский университет, Греция

\begin{abstract}
Aıм: The aim of this study was to investigate the influence of systematic training in physical growth and biological maturity in prepubertal males and estimate how this affects the physical growth and skeletal maturity. MATERIALS AND METHODS: 177 primary school students of the fifth and sixth grade, from schools in Alexandroupolis, participated voluntarily in our study. Questionnaires were used in order to measure physical activity levels. The subjects were subdivided into two groups; control group (prepubertal, whose physical activity was the physical education of their school and which had never participated in systematic training, $n=95$ ) and experimental group (prepubertal, whose weekly physical activity included physical education in their schools and additionally 3-4 training units organized training in various sports clubs in the city, $n=82$ ). The following parameters were recorded: biological age measured by determination of skeletal age; bone density measured by ultrasound methods; anthropometric and morphological features such as height, body composition, selected diameters, circumferences and skinfolds; motor ability features. Results: The experimental group exhibited older biological age $(p=0.033)$, higher bone density $(p<0.001)$, lower BMI and body fat $(p<0.001)$, better anthropometric features and higher performance throughout all motor ability tests $(\mathrm{p}<0.05)$, compared to the control group. ConcLUSION: The present study demonstrates that systematic physical activity has a positive effect on both the physical and biological maturity of pre-pubertal children. This effect is mainly expressed in bone strengthening as a result of the increased bone density and in improvement of the kinetic skills of pupils who participated in organized extracurricular sport-activities.
\end{abstract}

Key words: systematic training, young athletes, prepubertal, bone density

Folia Medica 2015;57(3\&4):223-229

Copyright (C) 2015 Medical University, Plovdiv

\section{РЕЗЮМЕ}

ЦЕль: Целью данной работы является исследование влияния системных занятий спортом на физическое развитие и биологическую зрелость подростков в пубертатном возрасте. МАтериАл и методы: Выборка содержит $(\mathrm{n}=177)$ добровольно принявших участие школьников пятых и шестых классов из основной школы города Александруполис. Уровни физической активности были оценены с помощью вопросников. Субъекты составили „контрольную группу” (подростки препубертатного возраста ( $\mathrm{n}=95)$, единственная физическая активность которых ограничивалась занятиями физкультурой в школе, без никакого участия в системных занятиях спортом) и „экспериментальную группу” (подростки препубертатного возраста $(\mathrm{n}=82)$, недельная физическая активность которых включала участие в занятиях по физическому воспитанию в школах и дополнялась трёх-четырёхкратными тренировочными занятиями в различных городских спортивных клубах). Зарегистрированы были следующие показатели: биологический возраст, установленный путём определения скелетной зрелости; плотность кости, установленная с помощью ультразвуковых методов; антропометрические и морфологические характеристики, включая рост, композиционный состав тела, выбранные диаметры, окружности и складки кожи; способность моторных функций. Результаты: Установлено, что „экспериментальная группа” демонстрирует опережение

Article's history: Received: 12 Apr 2015; Received in a revised form: 13 Nov 2015; Accepted: 10 Dec 2015

*Correspondence and reprint request to: K. Tilkeridis, Department of Orthopaedics and Traumatology, Democritus University of Thrace, Greece; E-mail: tilkerorth@yahoo.com

Democritus University of Thrace, medical School, Alexandroupolis, Greece 
биологического возраста ( $p=0.033)$, более высокую плотность кости ( $<<0.001)$, более низкие индекс массы тела (BMI) и процент телесного жира $(\mathrm{P}<0.001)$, более высокие антропометрические характеристики и более высокую производительность во всех тестах на проверку моторных функций $(\mathrm{p}<0.05)$ по сравнению с „контрольной группой”. ЗАключениє: Данное исследование показывает, что системная физическая активность оказывает положительное воздействие одновременно на физическую и биологическую зрелость подростков в препубертатном возрасте. Положительный эффект состоит главным образом в увеличении плотности кости и в улучшении кинетических способностей школьников, участвующих в организованных формах внешкольных занятий спортом.

Ключевые слова: системные занятия спортом, молодые спортсмены, препубертатный возраст, плотность кости

Folia Medica 2015;57(3\&4):223-229

(C) 2015 Все права защищены. Медицинский университет, Пловдив

\section{INTRODUCTION}

During childhood and especially the adolescence, a variety of changes at the physical level are observed. The physical changes, however, are accompanied by psychological changes, which cover to a degree the effect of various factors such as systematic training on the physical and biological maturity of children. Although it seems clear that exercise has a very beneficial effect on the physical growth of children, there is little evidence in the literature documenting with measurements and tests the beneficial effect of long-term exercise on physical growth of children.

It is widely recognised that exercise has a significant positive effect on biological maturity. ${ }^{1,2}$ On the other hand, there are studies ${ }^{3-5}$ that focus on the reverse relationship, highlighting that increasing maturity limits participation in sports. Other researchers ${ }^{6,7}$ suggest that there is positive relationship between biological maturity and physical activity. It is observed that the results for the relationship between physical activity and biological maturity vary. This could be a consequence of the use of different tools for the assessment of physical activity. ${ }^{6}$

An important parameter is the relationship between participation in physical activities and the health status of children - teenagers, concentrating on morphological differences and individual characteristics. Exercise and physical activity are considered essentials of normal child development. Increased physical activity during childhood reduces the likelihood of obesity and eventually it is related with healthfully regulated body ${ }^{8,9}$ increasing strength and endurance ${ }^{10}$, helping to prevent cardiovascular diseases $^{11,12}$, to combat the metabolic syndrome ${ }^{13,14}$. Additionally increased physical activity during childhood seems to have positive effects in preventing osteoporosis $^{15}$ and on high blood pressure ${ }^{16,17}$ later on during adulthood.
Physical activity has a significant influence on the motor skills of adolescents. ${ }^{18,19}$ There are several researchers ${ }^{20-22}$ who focus on the relationship between physical activity and bone development proving that children who train have better bone growth and long-term maintenance even after reduction or cessation of physical activity.

The above cases are reported in research that examines individual benefits of physical activity in children and adolescents. Relatively more limited is the research ${ }^{23,24}$ that examines the effects of regular physical activity to the physical growth of adolescent athletes. By the term systematic exercise we mean "participation in organized sports" (e.g. schools and clubs).

\section{AIM}

The aim of the present research was to investigate the impact of systematic training on physical growth and biological maturity in prepubertal males, and estimate how this affects the physical growth and skeletal maturity. More specific, the following parameters have been evaluated: 1) chronological and biological age, 2) anthropometric and morphological characteristics, 3) motor ability features and 4) bone mineral density.

\section{MATERIALS AND METHODS}

\section{PARTICIPANTS}

In order to investigate the effect of exercise on physical and biological maturity of pupils, strengthening of bones due to possible increase in bone density and their kinetic activity we compared the above four parameters among pupils-athletes who participated in different levels of sport activity. More specifically, these were pupils who were involved in various individual or team sports and pupils whose only sports activity was their weekly scheduled school physical education classes. The 
total sample consisted of 177 volunteers, primary school students, of the fifth and sixth grade, from schools in Alexandroupolis.

The pupils were divided into two groups:

A. Control group. Prepubertal children, whose physical activity included only the school scheduled physical education. Pupils of this group never participated in systematic training. This group included 95 students.

B. Experimental group. Prepubertal children, whose weekly physical activity included physical education in school and additionally 3-4 training units in various sports clubs in the city (collectively and individually). The experimental group comprised of 82 pupils-athletes.

For the survey the following measurements were investigated:

At baseline both the chronological and biological age were documented. The biological age was determined by assessing the skeletal age.

Bone density was measured with the Achilles Insight 2006 ultrasound system. This device determines the ultrasound properties of the heel and automatically calculates the stiffness index. In greater detail, each measurement recorded the speed of sound (SOS) and the Broadband Ultrasound Attenuation (BUA). Based on these indicators, Quantitative Ultrasound Index Stiffness (QUI) was calculated.

Regarding the morphological features, physical measurements (height, arm span, shank length, along top edge, arm length, forearm length, length, wrist/hand, leg length, thigh length, tibia length), diameter (acromial, pelvic - at the level of the iliac wings, humeral condyles, femoral condyles, wrist, anteroposterior, thoracis), circumferences (thoracic, arm, hip, thigh, forearm, calf) and body composition (body weight, body mass index (BMI), body fat, fat mass, lean body mass) were evaluated.

Skin thickness was measured using a "Lange" skin calliper. The following skinfolds were measured: biceps, triceps, gastrocnemius, femoral, abdomen, suprailiac and scapula.

Regarding motor skills the following tests were performed: Astrand-Rhyming $\mathrm{VO}_{2}$ max, shuttle run $10 \times 5 \mathrm{~m} \& 30 \mathrm{~m}$ running test, standing broad jump, vertical jump, Flamingo balance test, sit and reach test, handgrip test, sit ups, hanging with bent elbows, and pulls on a horizontal bar.

The measurements of the morphological and motor abilities, as well as the biological age and bone mineral density were applied once at the end of the pupil-coaching period. From the measurements all individuals who suffered from injuries or other upper and lower limb diseases at the time of the evaluation were excluded. All measurements were performed using the same equipment.

\section{STATISTICAL ANALYSIS}

Data were analysed using the Statistical Package for the Social Sciences (SPSS), version 19.0 (IBM). All subjects' characteristics were quantitative variables and they were expressed as mean \pm standard deviation. The normality of their distribution was tested using the Kolmogorov-Smirnov test. Student's $t$-test was used to assess the differences of subjects' characteristics between the experimental and control group. Effect size (ES) was described in terms of Cohen's $\mathrm{d}$. Values of Cohen's $\mathrm{d} \approx \pm 0.2$ represent a small effect, $\mathrm{d} \approx \pm 0.5$ represent a moderate effect and $\mathrm{d} \approx \pm 0.8$ represent a large effect. All tests were two tailed and statistical significance was considered for $\mathrm{p}<0.05$.

\section{RESULTS}

There was no statistically significant difference in children's chronological age between the two groups $(\mathrm{p}=0.383)$. However, there was a statistically significant difference with respect to the biological age; the mean biological age of pupilsathletes was greater compared to that of the control group $(12.15 \pm 1.26$ years vs $11.53 \pm 1.13$ years, $\mathrm{p}=0.033$ ). Additionally, there was a difference in the two groups regarding the bone density; the experimental group exhibited a higher speed of sound (SOS) by $9.547 \mathrm{~m} / \mathrm{sec}(0.6 \%)$ and a more wide ultrasonic spectrum (BUA) by $3.244 \mathrm{~dB} /$ $\mathrm{MHz}(3.1 \%)$. Therefore, the quantitative ultrasound index stiffness (QUI) was also significantly higher (by 6.7\%) for the experimental $(93.634 \pm 3.539 \mathrm{~g} /$ $\left.\mathrm{cm}^{2}\right)$ compared to the control $(87.788 \pm 3.044 \mathrm{~g} /$ $\mathrm{cm}^{2}$ ) group. All these differences were statistically significant (all $\mathrm{p}<0.001)$ (Table 1).

Table 2 presents the differences in the body composition and the skinfolds of the pupils of the two groups. Specifically, it was observed that although the control group shows a slightly higher mean body weight $(45.17 \pm 7.90 \mathrm{~kg})$ compared to the study group $(43.62 \pm 7.19 \mathrm{~kg})$, this difference did not reach the statistical significance $(\mathrm{p}=0.177)$. However, the study group presented statistically significantly lower body mass index (by $7.7 \%$, p $<0.001$ ), lower body fat (by $14.0 \%, \mathrm{p}<0.001$ ) and less fat mass (by 16.7\%, p < 0.001 ) compared to the control group. In contrast, no statistically significant difference was found in the lean body 
Table 1. Biological age and bone density of children in the experimental and control groups

\begin{tabular}{|c|c|c|c|c|c|c|}
\hline & $\begin{array}{c}\text { Experimental } \\
\text { group } \\
(\mathbf{n}=\mathbf{8 2}) \\
\text { mean } \pm \text { SD }\end{array}$ & $\begin{array}{c}\text { Control group } \\
(\mathrm{n}=95) \\
\text { mean } \pm \mathrm{SD}\end{array}$ & $\begin{array}{c}\text { Mean difference } \\
(95 \% \text { CI }) \\
\text { Experimental - } \\
\text { Control group }\end{array}$ & $\begin{array}{l}\text { Percentage }(\%) \\
\text { difference } \\
\text { Mean difference } \\
\text { x } 100 \text { / Control } \\
\text { group }\end{array}$ & $\mathbf{p}$ & $\begin{array}{c}\text { Cohen's } \\
\text { d }\end{array}$ \\
\hline $\begin{array}{l}\text { Training age } \\
\text { (years) }\end{array}$ & $2.20 \pm 0.96$ & - & - & - & - & - \\
\hline $\begin{array}{l}\text { Chronological } \\
\text { age (years) }\end{array}$ & $11.35 \pm 0.80$ & $11.45 \pm 0.72$ & $-0.10(-0.32$ to 0.12$)$ & -0.9 & 0.383 & - \\
\hline $\begin{array}{l}\text { Biological age } \\
\text { (years) }\end{array}$ & $12.15 \pm 1.26$ & $11.53 \pm 1.13$ & $0.62(0.06$ to 1.18$)$ & 5.4 & 0.033 & 0.52 \\
\hline \multicolumn{7}{|l|}{ Bone density } \\
\hline SOS & $1570.832 \pm 7.127$ & $1561.285 \pm 6.773$ & 9.547 (7.497 to 11.597$)$ & 0.6 & $<0.001$ & 1.37 \\
\hline BUA & $108.660 \pm 3.503$ & $105.416 \pm 3.024$ & $3.244(2.283$ to 4.206$)$ & 3.1 & $<0.001$ & 0.99 \\
\hline QUI & $93.634 \pm 3.539$ & $87.788 \pm 3.044$ & $5.846(4.876$ to 6.816$)$ & 6.7 & $<0.001$ & 1.77 \\
\hline
\end{tabular}

Table 2. Body composition and skinfolds of children in the experimental group and the control group

\begin{tabular}{|c|c|c|c|c|c|c|}
\hline & $\begin{array}{c}\text { Experimental } \\
\text { group } \\
(\mathbf{n}=\mathbf{8 2}) \\
\text { mean } \pm \text { SD }\end{array}$ & $\begin{array}{c}\begin{array}{c}\text { Control } \\
\text { group } \\
(\mathbf{n}=95) \\
\text { mean } \pm \text { SD }\end{array}\end{array}$ & $\begin{array}{c}\text { Mean difference } \\
(95 \% \text { CI }) \\
\text { Experimental - } \\
\text { Control group }\end{array}$ & $\begin{array}{c}\text { Percentage }(\%) \\
\text { difference } \\
\text { Mean differ- } \\
\text { ence } \times 100 \text { / } \\
\text { Control group }\end{array}$ & $\begin{array}{c}\mathbf{p} \\
\text { value }\end{array}$ & $\begin{array}{c}\text { Cohen's } \\
\text { d }\end{array}$ \\
\hline \multicolumn{7}{|l|}{ Body composition } \\
\hline Body weight $(\mathrm{kg})$ & $43.62 \pm 7.19$ & $45.17 \pm 7.90$ & $-1.55(-3.79$ to 0.69$)$ & -3.4 & 0.177 & 0.20 \\
\hline Body mass index $\left(\mathrm{kg} / \mathrm{m}^{2}\right)$ & $19.92 \pm 2.56$ & $21.57 \pm 2.83$ & $-1.65(-2.44$ to -0.86$)$ & -7.7 & $<0.001$ & 0.61 \\
\hline Body fat $(\%)$ & $16.13 \pm 3.40$ & $18.75 \pm 4.07$ & $-2.62(-3.74$ to -1.51$)$ & -14.0 & $<0.001$ & 0.69 \\
\hline Fat mass $(\mathrm{kg})$ & $7.09 \pm 1.89$ & $8.51 \pm 2.34$ & $-1.42(-2.05$ to -0.79$)$ & -16.7 & $<0.001$ & 0.66 \\
\hline Lean body mass $(\mathrm{kg})$ & $36.55 \pm 4.65$ & $36.69 \pm 5.11$ & $-0.14(-1.59$ to 1.31$)$ & -0.4 & 0.850 & 0.03 \\
\hline \multicolumn{7}{|l|}{ Skinfold (mm) } \\
\hline biceps & $8.97 \pm 3.55$ & $10.47 \pm 2.84$ & $-1.50(-2.44$ to -0.56$)$ & -14.3 & 0.002 & 0.47 \\
\hline triceps & $10.01 \pm 2.50$ & $12.30 \pm 3.67$ & $-2.29(-3.23$ to -1.35$)$ & -18.6 & $<0.001$ & 0.72 \\
\hline gastrocnemius & $13.52 \pm 4.33$ & $14.02 \pm 3.11$ & $-0.50(-1.60$ to 0.60$)$ & -3.6 & 0.374 & 0.13 \\
\hline femoral & $15.21 \pm 3.72$ & $17.53 \pm 4.20$ & $-2.32(-3.50$ to -1.14$)$ & -13.2 & $<0.001$ & 0.58 \\
\hline abdomen & $8.12 \pm 1.82$ & $10.07 \pm 2.32$ & $-1.95(-2.57$ to -1.33$)$ & -19.4 & $<0.001$ & 0.93 \\
\hline suprailiac & $6.79 \pm 1.90$ & $8.00 \pm 2.48$ & $-1.21(-1.87$ to -0.55$)$ & -15.1 & $<0.001$ & 0.54 \\
\hline scapula & $8.93 \pm 2.69$ & $10.56 \pm 3.10$ & $-1.63(-2.49$ to -0.77$)$ & -15.4 & $<0.001$ & 0.56 \\
\hline
\end{tabular}

mass between the two groups of pupils $(36.55 \pm$ $4.65 \mathrm{~kg}$ in the study group vs $36.69 \pm 5.11 \mathrm{~kg}$ in the control group, $\mathrm{p}=0.850)$. Furthermore, there were statistically significant differences $(p<0.001)$, for six of the seven skinfolds measured herein. In all cases the students-athletes showed smaller measures (in $\mathrm{mm}$ ) than the students of the control group. Larger differences were observed for abdominal (by 19.4\%) and the triceps (by 18.6\%) skinfolds. Finally, regarding the gastrocnemius skinfold, there was no statistically significant difference between the groups $(\mathrm{p}=0.374)$.

Additionally, there were statistically significant differences in the anthropometric characteristics of the pupils (Table 3). Specifically, pupils-athletes of the study group exhibited a greater height (by 3.34 $\mathrm{cm}, \mathrm{p}=0.002$ ), greater arm span (by $4.52 \mathrm{~cm}, \mathrm{p}$ $<0.001$ ), and greater length of the shank (by 1.43 $\mathrm{cm}, \mathrm{p}=0.026$ ), of the upper end (at $2.79 \mathrm{~cm}$, $\mathrm{p}<0.001$ ), of arm (by $2.08 \mathrm{~cm}, \mathrm{p}<0.001$ ), of lower limb (by $2.29 \mathrm{~cm}, \mathrm{p}=0.001$ ) and of thigh (by $2.30 \mathrm{~cm}, \mathrm{p}=0.002)$. On the other hand, differences for length of forearm $(p=0.427)$, wrist/ hand $(p=0.160)$ and leg $(p=0.103)$ did not reach statistical significance. Regarding the measurement of diameters, there were no statistically significant differences $(p>0.05)$, except for the diameter of the wrist. In this respect, the study group showed a greater diameter (by 3.9\%) compared to the control group $(4.55 \pm 0.51 \mathrm{~cm}$ vs $4.38 \pm 0.47 \mathrm{~cm}$, 
Table 3. Anthropometric characteristics of children in the experimental group and the control group

\begin{tabular}{|c|c|c|c|c|c|c|}
\hline & $\begin{array}{c}\text { Experimental } \\
\text { group } \\
(\mathrm{n}=\mathbf{8 2}) \\
\text { mean } \pm \mathrm{SD}\end{array}$ & $\begin{array}{l}\text { Control group } \\
\quad(n=95) \\
\text { mean } \pm \text { SD }\end{array}$ & $\begin{array}{c}\text { Mean difference } \\
(95 \% \mathrm{CI}) \\
\text { Experimental - } \\
\text { Control group }\end{array}$ & $\begin{array}{l}\text { Percentage }(\%) \\
\text { difference } \\
\text { Mean difference } \\
\text { x } 100 \text { / Control } \\
\text { group }\end{array}$ & $\begin{array}{c}\mathbf{p} \\
\text { value }\end{array}$ & $\begin{array}{c}\text { Cohen's } \\
\text { d }\end{array}$ \\
\hline \multicolumn{7}{|l|}{ Lenghts $(\mathrm{cm})$} \\
\hline Height & $148.20 \pm 7.07$ & $144.86 \pm 7.22$ & $3.34(5.45$ to 1.23$)$ & 2.3 & 0.002 & 0.47 \\
\hline Arm span & $150.07 \pm 9.02$ & $145.55 \pm 8.31$ & $4.52(1.97$ to 7.07$)$ & 3.1 & $<0.001$ & 0.52 \\
\hline Shank length & $50.05 \pm 4.35$ & $48.62 \pm 4.10$ & $1.43(0.18$ to 2.68$)$ & 2.9 & 0.026 & 0.34 \\
\hline Along top edge & $66.25 \pm 4.55$ & $63.46 \pm 4.60$ & $2.79(1.44$ to 4.14$)$ & 4.4 & $<0.001$ & 0.61 \\
\hline Arm length & $28.88 \pm 2.47$ & $26.80 \pm 2.35$ & 2.08 (1.37 to 2.79$)$ & 7.8 & $<0.001$ & 0.86 \\
\hline Forearm length & $22.35 \pm 2.11$ & $22.07 \pm 2.51$ & $0.28(-0.41$ to 0.97$)$ & 1.3 & 0.427 & 0.12 \\
\hline Length wrist / hand & $15.02 \pm 2.05$ & $14.59 \pm 2.00$ & $0.43(-0.17$ to 1.03$)$ & 2.9 & 0.160 & 0.21 \\
\hline Leg length & $79.34 \pm 5.00$ & $77.05 \pm 4.16$ & $2.29(0.94$ to 3.64$)$ & 3.0 & 0.001 & 0.50 \\
\hline Thigh length & $37.40 \pm 3.81$ & $35.10 \pm 4.16$ & $2.30(1.12$ to 3.48$)$ & 6.6 & $<0.002$ & 0.57 \\
\hline Tibia length & $37.26 \pm 5.06$ & $36.02 \pm 4.97$ & $1.24(-0.24$ to 2.72$)$ & 3.4 & 0.103 & 0.25 \\
\hline
\end{tabular}

Table 4. Motor ability tests of children in the experimental group and the control group

\begin{tabular}{|c|c|c|c|c|c|c|}
\hline & $\begin{array}{c}\text { Experimental } \\
\text { group } \\
(\mathbf{n}=\mathbf{8 2}) \\
\text { mean } \pm \text { SD }\end{array}$ & $\begin{array}{l}\text { Control group } \\
\quad(n=95) \\
\text { mean } \pm \text { SD }\end{array}$ & $\begin{array}{c}\text { Mean difference } \\
(95 \% \mathrm{CI}) \\
\text { Experimental - } \\
\text { Control group }\end{array}$ & $\begin{array}{c}\text { Percentage } \\
(\%) \\
\text { difference } \\
\text { Mean differ- } \\
\text { ence x } 100 \\
\text { / Control } \\
\text { group }\end{array}$ & $\underset{\text { value }}{p}$ & $\begin{array}{c}\text { Cohen's } \\
\text { d }\end{array}$ \\
\hline $\begin{array}{l}\text { Astrand-Rhyming } \mathrm{VO}_{2} \max \\
\left(\mathrm{ml} \times \mathrm{kg}^{-1} \times \min ^{-1}\right)\end{array}$ & $34.34 \pm 3.09$ & $29.74 \pm 2.71$ & $4.60(3.75$ to 5.45$)$ & 15.5 & $<0.001$ & 1.59 \\
\hline Shuttle run $10 \times 5 \mathrm{~m}(\mathrm{sec})$ & $21.03 \pm 2.95$ & $23.15 \pm 2.31$ & $-2.12(-2.89$ to -1.34$)$ & -9.2 & $<0.001$ & 0.81 \\
\hline Run 30 m (sec) & $12.20 \pm 1 . \mathrm{a} 10$ & $13.25 \pm 1.24$ & $-1.05(-1.40$ to -0.70$)$ & -7.9 & $<0.001$ & 0.89 \\
\hline Standing broad jump $(\mathrm{cm})$ & $164.70 \pm 21.18$ & $147.12 \pm 18.20$ & 17.58 (11.78 to 23.38$)$ & 11.9 & $<0.001$ & 0.90 \\
\hline Vertical jump $(\mathrm{cm})$ & $28.62 \pm 5.11$ & $21.40 \pm 4.59$ & $7.22(5.79$ to 8.65$)$ & 33.7 & $<0.001$ & 1.49 \\
\hline Flamingo balance test (fall) & $12.00 \pm 3.55$ & $13.50 \pm 3.80$ & $-1.50(-2.59$ to -0.41$)$ & -11.1 & 0.008 & 0.41 \\
\hline Sit and reach test $(\mathrm{cm})$ & $17.69 \pm 4.66$ & $12.18 \pm 4.31$ & $5.51(4.19$ to 6.83$)$ & 45.2 & $<0.001$ & 1.23 \\
\hline Handgrip test $(\mathrm{kg})$ & $21.75 \pm 4.10$ & $19.05 \pm 3.48$ & 2.70 (1.58 to 3.82$)$ & 14.2 & $<0.001$ & 0.71 \\
\hline Sit ups (no) & $23.50 \pm 4.22$ & $16.28 \pm 3.90$ & $7.22(6.02$ to 8.42$)$ & 44.3 & $<0.001$ & 1.78 \\
\hline $\begin{array}{l}\text { Hanging with bent elbows } \\
(\mathrm{sec})\end{array}$ & $11.85 \pm 3.61$ & $9.54 \pm 3.88$ & $2.31(1.20$ to 3.42$)$ & 24.2 & $<0.001$ & 0.61 \\
\hline Pulls at horizontal bar (no) & $2.05 \pm 2.18$ & $1.34 \pm 2.01$ & $0.71(0.09$ to 1.33$)$ & 53.0 & 0.025 & 0.34 \\
\hline
\end{tabular}

$\mathrm{p}=0.022)($ Table 3$)$.

For the measurements of the body perimeters, statistically significant differences between the two groups were observed in three of the six perimeters measured herein; pupils-athletes showed greater perimeters compared to pupils of the control group. In particular, the thoracic perimeter of the study group was increased by $3.1 \%(79.68 \pm 4.55 \mathrm{~cm}$ vs $77.28 \pm 5.62 \mathrm{~cm}, \mathrm{p}=0.002)$, the arm perimeter was increased by $4.5 \%(26.90 \pm 2.32 \mathrm{~cm}$ vs $25.74 \pm 2.10 \mathrm{~cm}, \mathrm{p}=0.017)$ and the gastrocnemius perimeter was also increased by $3.6 \%$ (31.12 \pm $2.91 \mathrm{~cm}$ vs $30.04 \pm 3.05 \mathrm{~cm}, \mathrm{p}=0.017)$. For the other three body perimeters such as the forearm 
$(\mathrm{p}=0.939)$, hip $(\mathrm{p}=0.275)$ and thigh $(\mathrm{p}=0.087)$, there were no statistically significant differences between the two groups (Table 3).

Finally, pupils-athletes of the study group showed better performance throughout all motor ability tests (Table 4). In particular, pupils-athletes showed higher values in Astrand-Rhyming $\mathrm{VO}_{2}$ max (by $15.5 \%, \mathrm{p}<0.001$ ), in standing broad jump (by $17.58 \mathrm{~cm}$ or $11.9 \%, \mathrm{p}<0.001)$, in vertical jump (by $7.22 \mathrm{~cm}$ or $33.7 \%, \mathrm{p}<0.001$ ), in sit and reach test $(5.51 \mathrm{~cm}$ or $45.2 \%, \mathrm{p}<0.001)$, in handgrip test (at $2.70 \mathrm{~kg}$ or $14.2 \%, \mathrm{p}<0.001$ ), in sit ups (at 7.22 sit ups or $44.3 \%, \mathrm{p}<0.001$ ), as well as in hanging with bent elbows on horizontal bars (at $2.31 \mathrm{sec}$ or $24.2 \%, \mathrm{p}<0.001)$ and in pulls on a horizontal bar (at 0.71 or $53.0 \%, \mathrm{p}=0.025$ ). Additionally, the control group showed lower speed in the shuttle run $-10 \times 5 \mathrm{~m}$ (by $2.12 \mathrm{sec}$ or $9.2 \%$, $\mathrm{p}<0.001$ ) and in the speed run of $30 \mathrm{~m}$ (by 1.05 sec or $7.9 \%, p<0.001)$. At the Flamingo balance test, pupils-athletes had fewer falls (by 1.50 falls or $11.1 \%, \mathrm{p}=0.008)$ compared to the control group.

\section{DISCUSSION}

According to the findings of the primary research, although in the two groups there were children of the same chronological age, there was a significant difference in biological age, which was higher among pupils-athletes. Our findings demonstrate that physical activity contributes to an earlier maturation (development). In addition, pupils-athletes showed greater bone density, demonstrating that systematic training promotes bone growth and maturation. Other researchers, too, have demonstrated this effect. ${ }^{20-22}$ They clearly demonstrated that systematic exercise has a positive impact on bone growth of children and adolescents mainly because it increases the concentration of minerals in bones and peak bone mass.

On the other hand, in accordance with previous studies $^{8,12}$, our study supports the view that systematic exercise is an important factor for maintaining good health in children and consequently improves their quality of life. This stems from the fact that pupils-athletes had a lower body mass index, lower body fat and lower fat mass compared with pupils whose only involvement in the exercise is the physical education in school. This is also demonstrated by the fact that the group of pupils-athletes had smaller skinfolds, especially the abdominal, triceps and femoral ones. This result indicates that systematic training helps to reduce the fat from the most difficult body signals, which is consistent with the findings of previous studies by other researchers. ${ }^{23}$

The present study demonstrates that systematic training affects the physical growth of prepubertal, as children who participated in organized training had greater height, opening hands, as well as greater length of torso, upper limb, arm, leg and thigh. Besides, pupils-athletes also showed greater circumference of chest, arm and calf. This development seems quite logical, since, in the adolescent period the growth of muscle mass in boys is twice the growth rate of girls. Along with systematic training course, this growth is even more pronounced. ${ }^{25}$

\section{CONCLUSIONS}

The present study demonstrates that systematic training has significant positive effects on motor abilities of preadolescent, since children who play sports showed higher values in the Astrand-Rhyming $\mathrm{VO}_{2}$ max, in standing broad jump, in vertical jump, in sit and reach test, in handgrip test, in sit ups, as well as in isometric and dynamic pull. Also, children had higher speed (e.g., at shuttle run 10x5 m and run $30 \mathrm{~m}$ test) and better balance in Flamingo test. The relationship between systematic physical activities and motor abilities has been also shown by other researchers. ${ }^{18}$

The present study proves that the systematic physical activity has a positive effect on both the physical and the biological maturity of children in prepubertal age. This effect is mainly expressed in strengthening bones as a result of the increased bone density and the improved motor skills of students that participate in organized sports besides the scheduled school activities.

\section{REFERENCES}

1. Smart JE, Cumming SP, Sherar LB, et al. Maturity associated variance in physical activity and health-related quality of life in adolescent females: a mediated effects model. J Phys Act Health 2012;9(1):86-95.

2. Sherar LB, Esliger DW, Baxter-Jones AD, et al. Age and gender differences in youth physical activity: Does physical maturity matter? Med Sci Sports Exerc 2007;39(5):830-5.

3. Cumming SP, Sherar LB, Smart JE, et al. Physical Activity, Physical Self-Concept, and Health-Related Quality of Life of Extreme Early and Late Maturing Adolescent Girls. J Earl Adolesc 2012;32(2):269-92.

4. Drenowatz C, Eisenmann JC, Pfeiffer KA, et al. Maturity-related differences in physical activity among 10-to-12-year-old girls. Am J Hum Biol 2010;22(1):18-22. 
5. Erlandson MC, Sherar LB, Mosewich AD, Kowalski KC, Bailey DA, Baxter-Jones AD. Does controlling for biological maturity improve physical activity tracking? Med Sci in Sports and Exerc 2011;43(5):800-7.

6. Fairclough SJ, Boddy LM, Ridgers ND, et al. Biological maturity and primary school children's physical activity: Influence of different physical activity assessment instruments. Eur J Sport Sci 2011;11(4):241-8.

7. Machado Rodrigues AM, Coelho E Silva MJ, Mota $\mathrm{J}$, et al. Confounding effect of biologic maturation on sex differences in physical activity and sedentary behaviour in adolescents. Pediatr Exerc Sci 2010;22(3):442-53.

8. DuRant RH, Baranowski T, Rhodes T, et al. Association among serum lipid and lipoprotein concentration and physical activity, physical fitness, and body composition in young children. J Pediatr 1993;123(2):185-92.

9. Guinhouya BC. Physical activity in the prevention of childhood obesity. Paediatric Perinatal Epidemiol 2012;26(5):438-47.

10. Baláš J, Strejcová B, Malý T, et al. Changes in upper body strength and body composition after 8 weeks indoor climbing in youth. Isok Exerc Sci 2009;17(3):173-9.

11. Andersen LB, Harro M, Sardinha LB, et al. Physical activity and clustered cardiovascular risk in children: a cross-sectional study (The European Youth Heart Study). Lancet 2006;22:368(9532):299-304.

12. Drenowatz C, Steiner RP, Brandstetter S, et al. Organized sports, overweight, and physical fitness in primary school children in Germany. J Obes 2013:935245. doi: 10.1155/2013/935245. Epub 2013 Feb 28.

13. Ekelund U, Brage S, Froberg K, et al. Andersen LB. TV viewing and physical activity are independently associated with metabolic risk in children: The European youth heart study. PLoS Med 2006;3(12): e 488 .

14. Guinhouya BC, Hubert H. Insight into physical activity in combating the infantile metabolic syndrome.
Environ Health Prev Med 2011;16(3):144-7.

15. Boreham C, Riddoch C. The physical activity, fitness and health of children. J Sports Sci 2001;19(12): 915-29.

16. Barros MV, Ritti-Dias RM, Honda Barros SS, et al. Does self-reported physical activity associate with high blood pressure in adolescents when adiposity is adjusted for? J Sports Sci 2013;31(4):387-95.

17. Knowles G, Pallan M, Thomas GN, et al. Physical activity and blood pressure in primary school children: A longitudinal study. Hypertension 2013;61(1):70-5.

18. Matvienko O, Ahrabi-Fard I. The effects of a 4-week after-school program on motor skills and fitness of kindergarten and first-grade students. Am J Health Promot 2010;24(5):299-303.

19. Matthys SP, Vaeyens R, Coelho-E-Silva MJ, et al. The contribution of growth and maturation in the functional capacity and skill performance of male adolescent handball players. Int J Sports Med 2012;33(7):543-9.

20.Baptista F, Fragoso I, Branco J, et al. Reference Data for Bone Speed of Sound in Portuguese Girls and Boys Aged 9-13 Years. J Clin Densitom 2011;14(4):484-91.

21. Kennedy K, Shepherd S, Williams JE, et al. Activity, body composition and bone health in children. Arch Dis Child 2013;98(3):204-7.

22. Klentrou P, Ludwa IA, Falk B. Factors associated with bone turnover and speed of sound in early and late-pubertal females. Appl Physiol Nutr Metab 2011;36(5):707-14.

23. Bencke J, Damsgaard R, Saekmose A, et al. Anaerobic power and characteristics of muscles strength of 11-year-old elite and no elite boys and girls athletes of gymnastics, handball, volleyball and swimming. Scand J Med Sci Sports 2002;12(3):171-8.

24. Mandadzhieva S, Marinov B, Kostianev S, et al. Anthropometric and cardiopulmonary parameters in Bulgarian and Romany children: cross-sectional study. Croat Med J 2005;46(2):294-01.

25. Slinger J, van Breda E, Kuipers H. Aerobic fitness data for Dutch adolescents (2002-2005). Pediatr Exerc Sci 2009;21(1):10-8. 